\title{
Electrospun Polysaccharidic Textiles for Biomedical Applications
}

\author{
Daria Poshina $^{1}$ (D) and Issei Otsuka ${ }^{2, *(\mathbb{D})}$ \\ 1 Institute of Macromolecular Compounds of the Russian Academy of Sciences, Bolshoy pr. V.O. 31, \\ 199004 St. Petersburg, Russia; poschin@yandex.ru \\ 2 Université Grenoble Alpes, CNRS, CERMAV, 38000 Grenoble, France \\ * Correspondence: issei.otsuka@cermav.cnrs.fr
}

check for

updates

Citation: Poshina, D.; Otsuka, I. Electrospun Polysaccharidic Textiles for Biomedical Applications. Textiles 2021, 1, 152-169. https://doi.org/ 10.3390/textiles 1020007

Academic Editor: Selestina Gorgieva

Received: 27 May 2021

Accepted: 24 June 2021

Published: 30 June 2021

Publisher's Note: MDPI stays neutral with regard to jurisdictional claims in published maps and institutional affiliations.

Copyright: (C) 2021 by the authors Licensee MDPI, Basel, Switzerland. This article is an open access article distributed under the terms and conditions of the Creative Commons Attribution (CC BY) license (https:/ / creativecommons.org/licenses/by/ $4.0 /)$.

\begin{abstract}
Recent developments in electrospinning technology have enabled the commercial-scale production of nonwoven fabrics from synthetic and natural polymers. Since the early 2000s, polysaccharides and their derivatives have been recognized as promising raw materials for electrospinning, and their electrospun textiles have attracted increasing attention for their diverse potential applications. In particular, their biomedical applications have been spotlighted thanks to their "green" aspects, e.g., abundance in nature, biocompatibility, and biodegradability. This review focuses on three main research topics in the biomedical applications of electrospun polysaccharidic textiles: (i) delivery of therapeutic molecules, (ii) tissue engineering, and (iii) wound healing, and discusses recent progress and prospects.
\end{abstract}

Keywords: electrospinning; polysaccharides; textiles; nanofibers; therapeutic molecular delivery; tissue engineering; wound healing

\section{Introduction}

Electrospinning, a simple and versatile manufacturing method that uses high electric fields to draw polymer solutions or melts for the production of continuous nanofibers and their nonwoven fabrics (Figure 1), has come to be recognized as an important technique in the textile industry [1-4]. Electrospun nanofibers and their nonwoven fabrics have superior structural properties such as high specific surface area (up to $1000 \mathrm{~m}^{2} / \mathrm{g}$ ), nanoscale interstitial space, tunable porosity, and mechanical resistance. These properties make the electrospun textiles promising scaffolds for various applications. In recent years, electrospun materials have attracted ever increasing interest not only in conventional textile industries (e.g., production of yarn, cloth, and clothing) but also in innovative research fields including basic and applied biomedical research [5-16] for drug delivery, tissue engineering, wound healing, biosensor development, etc. In addition, the coronavirus disease 2019 (COVID-19) outbreak has caused a sudden rise in demand for personnel protective equipment represented by disposable nonwoven face masks, highlighting the utility of electrospun textiles such as the filters of masks that efficiently block nano-scale contaminants such as viruses [17].

Electrospun textiles made of natural polymers such as proteins, nucleic acids, and polysaccharides are promising materials for biomedical applications $[18,19]$ thanks to their inherent biocompatibility and abundance in nature. Among them, electrospun polysaccharidic textiles are relatively new materials [20-26]. Since the first electrospun cellulosic textile was reported by Liu and Hsieh in 2002 [27], the number of publications concerning electrospinning of polysaccharides and their derivatives has been increasing year by year, as shown in Figure 2. The preparation of defect-free nanofibrous polysaccharidic textiles via the electrospinning of natural polysaccharides [28-37] is challenging due to their limited choices of solvents and/or poor solubility. In some cases, polysaccharides are chemically functionalized to improve their solubility. For example, cellulose is poorly soluble in most organic solvents due to its strong inter- and intra-molecular hydrogen bonds and 
highly crystalline nature. Hence, one has been focused on the electrospinning of cellulose derivatives, particularly cellulose acetate, that exhibit good solubility in many organic solvents suitable for electrospinning. Electrospinning is then followed by the regeneration of cellulose via deprotection of the functional groups [25]. Blending with other polymers often facilitates the electrospinning process of polysaccharides and their derivatives by creating entanglements and physical bonds between the polymer chains. Biocompatible synthetic polymers, including poly(ethylene oxide): PEO [38-42], poly(vinyl alcohol): PVA [28,40,42-44], poly(lactic acid): PLA [45], poly( $\varepsilon$-caprolactone): PCL [46], as well as natural polymers (e.g., silk fibroin [47], zein [48], and collagen [49]), were blended with various polysaccharides and their derivatives and electrospun to fabricate polysaccharidic textiles. Details of the fabrication processes of polysaccharidic textiles via electrospinning have been given in several review articles and book chapters [20-26,50], including our recent report [51].

a)

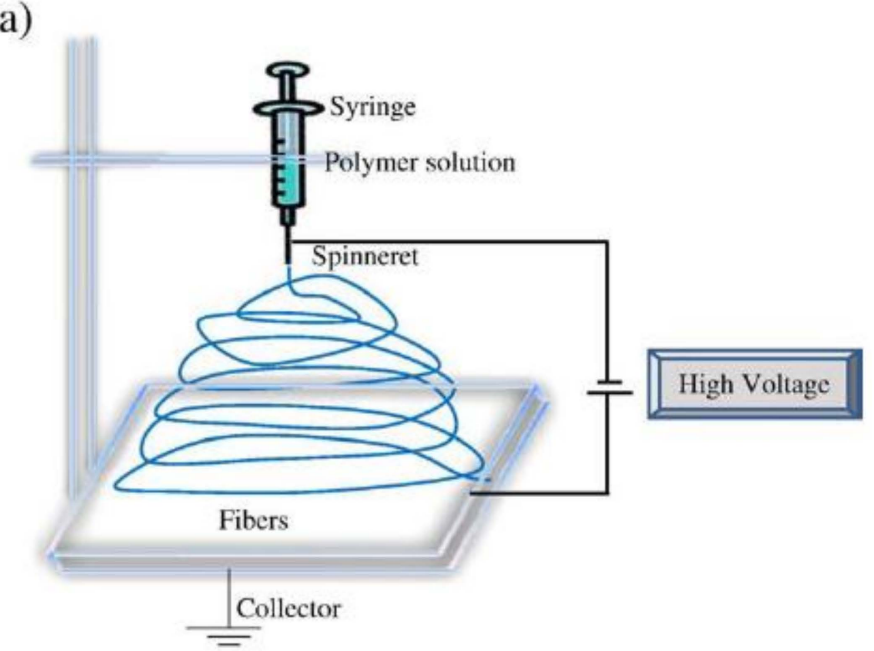

b)

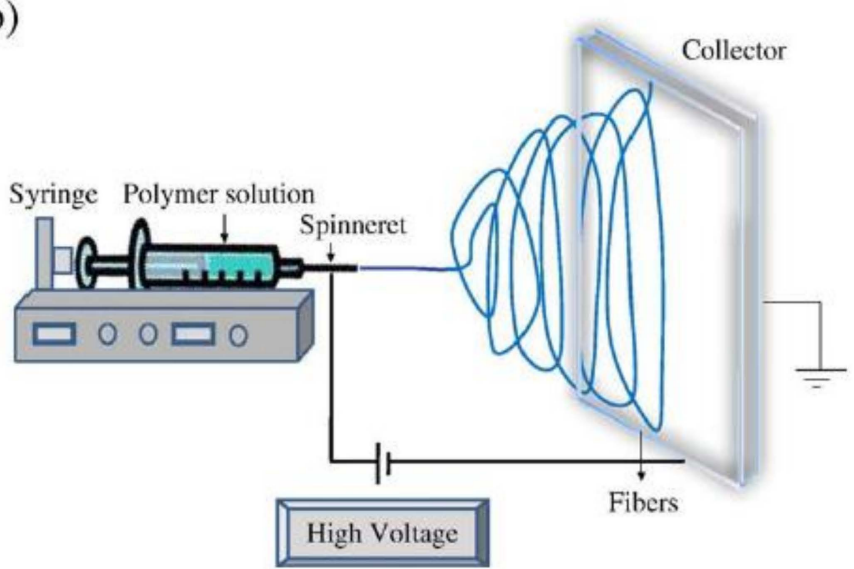

Figure 1. Schematic diagram of typical setups of an electrospinning apparatus: (a) vertical setup and (b) horizontal setup. Reprinted with permission from ref. [4]. Copyright 2010 Elsevier.

Despite the great attention that has been paid to polysaccaridic textiles, to the best of our knowledge, there is no comprehensive review of their biomedical applications that covers up-to-date electrospun polysaccaridic textiles reported in the late 2010s and 2020s. In this review, we highlight the potential of electrospun polysaccharidic textiles as promising scaffolds for the following three significant biomedical application targets: (i) delivery of therapeutic molecules, (ii) tissue engineering, and (iii) wound healing, and we discuss recent progress in these areas. 


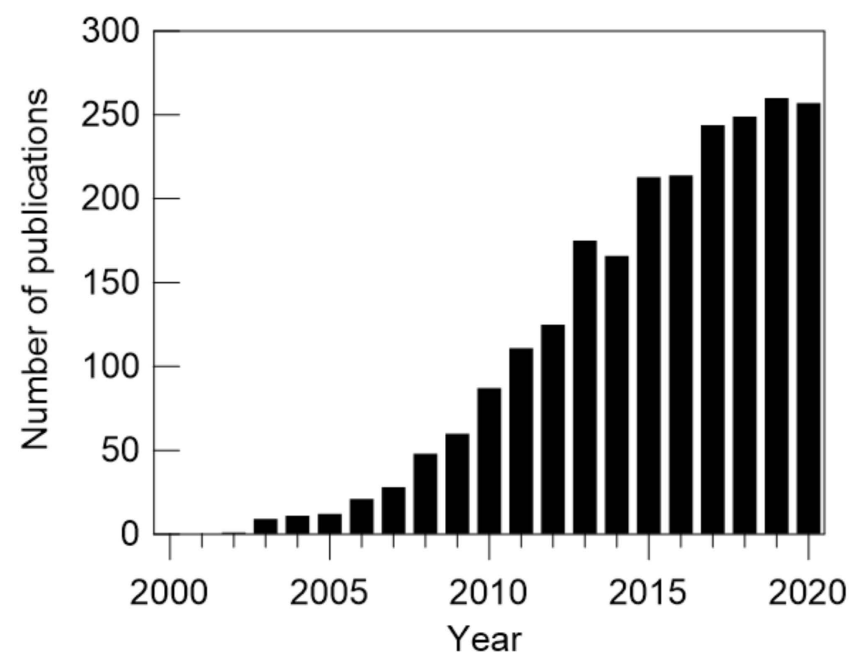

Figure 2. Number of publications (2000-2020) concerning electrospinning of polysaccharides and their derivatives (source: SciFinder-n, https:/ / scifinder-n.cas.org accessed on 20 April 2021).

\section{Biomedical Applications of Electrospun Polysaccharidic Textiles}

\subsection{Delivery of Therapeutic Molecules}

Electrospun nanofibrous textiles are considered promising for the immobilization of therapeutic molecules such as drugs, enzymes, and nucleic acids owing to their high specific surface area and porous structure [6-8,14,15]. Electrospun nanofibers are structurally similar to the extracellular matrices (ECMs) of tissues in the body: fibrous collagen structures in the ECM are on the scale of nanometers (50-500 $\mathrm{nm}$ in diameter). In particular, those made of polysaccharides are known to be biocompatible and are thus used as the scaffold of therapeutic molecular delivery systems $[23,52,53]$. In general, polysaccharides or their derivatives are dissolved in solvents in which therapeutic molecules are dispersed or dissolved, then electrospun to form textiles incorporating the therapeutic molecules. Coaxial electrospinning, a modified electrospinning process in which two concentrically aligned nozzles are used for spinning two different systems to generate nanofibers with "core-shell" morphologies (Figure 3), is another method to load therapeutic molecules into electrospun core-shell nanofibers. In coaxial electrospinning, therapeutic molecules are generally situated in the inner jet with some polymer matrixes and co-electrospun with polysaccharides or their derivatives present in the outer jet. In such ways, one can incorporate various therapeutic molecules within the polysaccharidic textiles and enhance the bioavailability of the therapeutic molecules by increasing their stability and circulation time in the body (Figure 4).
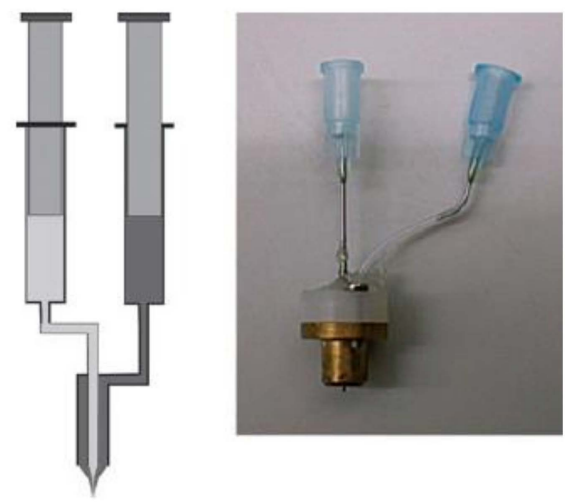

Figure 3. Left: A setup for coaxial electrospinning. Right: The experimental setup for coaxial electrospinning used in the laboratory of A. Greiner and J.H. Wendorff. Reprinted with permission from ref. [3]. Copyright 2007 from John Wiley and Sons. 
(a) Single Electrospinning Process
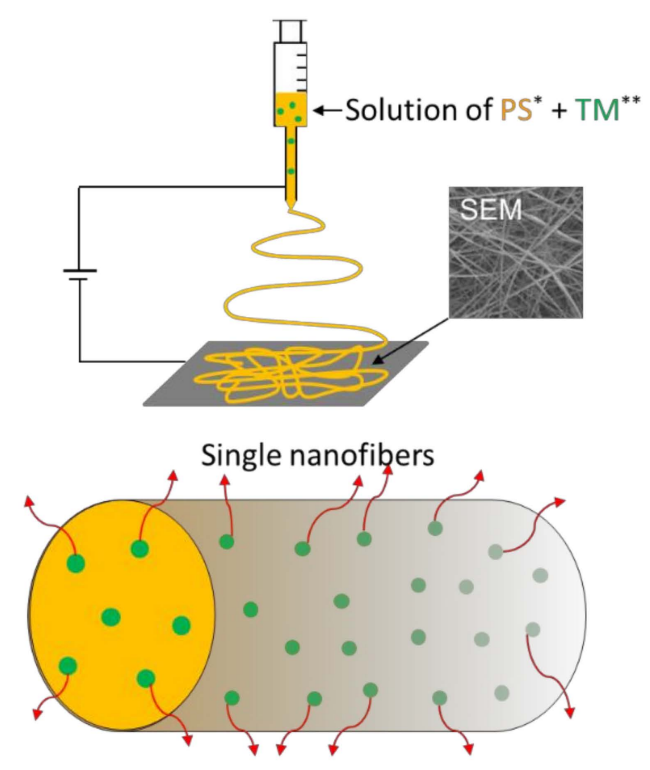

Burst release (b) Coaxial Electrospinning Process

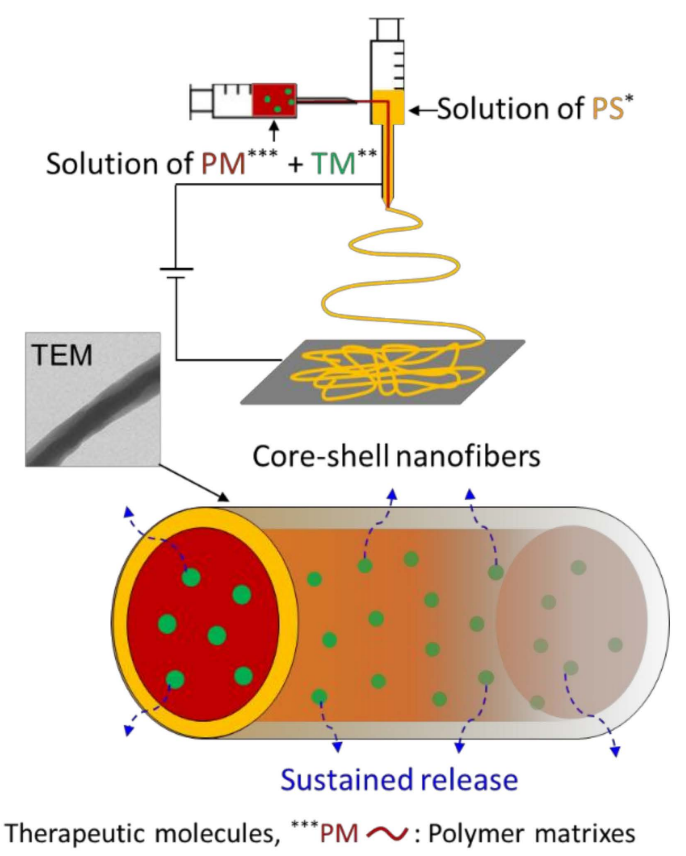

Figure 4. Schematic illustrations of encapsulations of therapeutic molecules via (a) a single electrospinning process and the resulting single nanofibers that show a burst release profile, and (b) a coaxial electrospinning process and the resulting core-shell nanofibers that show a sustained release profile.

Cellulose acetate, a semi-synthetic polymer derived from natural cellulose via an acetylation process, has been widely used for therapeutic molecular delivery systems thanks to its biodegradability and good mechanical, chemical, and thermal resistances [52,53]. Nonsteroidal anti-inflammatory drugs (NSAIDs) such as naproxen, indomethacin, ibuprofen, sulindac, and ketoprofen were incorporated into electrospun textiles made of cellulose acetate to be used in topical/transdermal delivery systems. Tungprapa et al. [54] reported electrospun nanofibers of cellulose acetate loaded with four types of NSAIDs (naproxen, indomethacin, ibuprofen, and sulindac) that are utilized in the symptomatic management of painful and inflammatory conditions. These drug-loaded textiles showed superior drugrelease profiles compared to those of drug-loaded cast films due to their great swelling in buffer solutions that originates from their nanofibrous structure. Yang et al. [55] reported electrospun core-shell nanofibers consisting of ibuprofen dispersed in the core-matrix of gliadin within an outer shell layer of cellulose acetate. The drug release studies showed that the presence of the cellulose acetate coating eliminated the initial burst release of ibuprofen and extended the release duration. Yu et al. [56,57] reported incorporations of ketoprofen within cellulose acetate nanofibers prepared via single and modified coaxial electrospinning processes. A zero-order drug release profile without initial burst effects and terminal tailing-off release was achieved with the textiles prepared by the modified coaxial electrospinning process that had a smaller diameter, narrower length distribution, more uniform structures, and smoother texture morphologies compared to those prepared by the single electrospinning process. Chung and Kwak [58] prepared a series of sulindacloaded electrospun nanofibers of cellulose acetate having various mean diameters and they studied the nano-confinement effects on their drug release properties. They demonstrated that the molecular mobility of the cellulose acetate/sulindac nanofibers and the diffusion coefficient of the drug decrease significantly with a decrease in the nanofiber diameter. Therefore, it was revealed that the drug tends to be slowly released with decreasing diameter of the nanofibers. Anticancer drugs such as cisplatin and silymarin were also incorporated into electrospun cellulose acetate nanofibers for their topical/transdermal deliveries. Absar et al. [59] reported the encapsulation of cisplatin into nanofibers prepared 
by the coaxial electrospinning of cellulose acetate as an outer jet and cisplatin as an inner jet. The drug-loaded nanofibers showed various architectures and morphological features depending on the core/shell compositions and the process parameters. Phiriyawirut and Phaechamud [60] prepared silymarin-loaded nanofibrous textiles by the electrospinning of mixed solutions of cellulose acetate and various amounts of silymarin. The loading content of silymarin significantly affected the glass transition temperature and the melting temperature of the textiles, as well as the drug release behavior. The incorporated silymarin was gradually released from the textiles over $480 \mathrm{~h}$. Other active agents such as antioxidants, antimicrobials, and antibiotics were also incorporated into electrospun textiles made of cellulose acetate, mainly for wound healing applications, which is described below in Section 2.3.

Chitin, the second most abundant natural polymer, is obtained from the exoskeletons of insects/crustaceans and also from the cell walls of fungi; and chitosan, the deacetylated form of chitin, has been extensively used in many biomedical applications due to its biocompatibility, biodegradability, cellular binding capability, acceleration of wound healing, hemostatic properties, and anti-bacterial/fungal properties [61-64]. Electrospun nanofibrous textiles made of chitosan have found potential as therapeutic molecular delivery systems. Jiang et al. [65] prepared ibuprofen-loaded fibrous membranes composed of poly(lactide-co-glycolide) (PLGA) and poly(ethylene glycol)-g-chitosan (PEG- $g$-chitosan) by electrospinning. The presence of PEG- $g$-chitosan significantly reduced the initial burst of ibuprofen and sustained its release from the membranes for more than 2 weeks due to the conjugation between ibuprofen and the side chains of PEG- $g$-chitosan. Mendes et al. [26] prepared electrospun chitosan/phospholipid nanofibrous textiles that encapsulate three model drugs (curcumin, diclofenac, and vitamin B12) for transdermal drug delivery. A sustained release of curcumin from the textile was observed over a period of 7 days with no significant burst effect, while the other two drugs showed initial burst releases within several hours due to their hydrophilic nature. Faralli et al. [66] prepared curcumin-loaded electrospun xanthan/chitosan nanofibrous textiles by electrospinning and incubated them with human Caco-2 cells to investigate cell viability, transepithelial transport, and permeability properties across cell monolayers. A consistent enhancement of the in vitro intestinal absorption of curcumin across cell monolayers was observed when it was loaded into the textiles. A 3.4-fold increase in curcumin permeability was observed with the curcumin-loaded textiles in comparison with free curcumin. Rostami et al. [67] prepared chitosan/gellan electrospun nanofibrous textiles that encapsulate resveratrol, a polyphenolic compound known as a drug for gastrointestinal cancer via oral delivery. The antioxidant activities of the resveratrol-loaded textiles were significantly higher than that of free resveratrol thanks to the large surface area of the nanofibers and hydrogen-donating ability of the chitosan moiety. Huang et al. [68] immobilized lipase, an enzyme that catalyzes hydrolyses of fats, in nanofibrous chitosan/PVA textiles using glutaraldehyde as a coupling agent. The $\mathrm{pH}$ and thermal stabilities of lipase were improved by its immobilization on the chitosan nanofibrous textiles. In addition, the reusability and storage stability of the immobilized lipase in the textiles were obviously higher than those of the nonimmobilized one.

Hyaluronic acid, an anionic nonsulfated glycosaminoglycan, is a main component of the ECM of connective, epithelial, and neural tissues. Because of its excellent biocompatibility, biodegradability, and nonimmunogenicity, hyaluronic acid and its derivatives have been extensively used, mostly in the form of a hydrogel, in various biomedical applications [69], including therapeutic molecular delivery [70]. In recent years, nanofibrous textiles consisting of hyaluronic acid and its derivatives have been prepared for use in therapeutic molecular delivery systems, as well as in tissue engineering and wound healing described below. Snetkov et al. [71,72] prepared curcumin/usnic acid-loaded electrospun nanofibrous textiles based on native hyaluronic acid without any carrier polymers and modifiers. The authors proposed potential applications of the pure hyaluronic acid-based textiles for wound dressing and drug delivery scaffolds. Agrahari et al. [73] reported electrospun core-shell nanofibers consisting of the outer shell layer composed of thiolated 
hyaluronic acid and the inner core composed of tenofovir (TFV), an anti-HIV vaginal microbicide, dispersed in PEO matrix. The TFV-loaded textiles showed a triggered release of TFV on exposure to the seminal hyaluronidase enzyme through in vitro drug release experiments. The TFV-loaded textiles were able to increase the retention of TFV and provided a higher drug bioavailability in vaginal tissue, including a lower drug disposition to rectum tissue compared with a TFV-loaded gel made of hydroxyethyl cellulose.

Other polysaccharides and their derivatives such as pullulan, sodium alginate, and guar gum were electrospun with therapeutic molecules to form nanofibrous textiles as delivery scaffolds. Mascheroni et al. [74] reported a bioactive aroma compound, perillaldehydeloaded electrospun nanofibrous textiles composed of pullulan and $\beta$-cyclodextrin. The textile hosts homogeneously dispersed $\beta$-cyclodextrin/aroma complexes, which are formed during electrospinning. The textiles showed a humidity-triggered release of the aroma compound. Ponrasu et al. [75] prepared Jelly fig polysaccharide (JFP)/pullulan nanofibrous textiles, which encapsulate hydrophobic model drugs (ampicillin and dexamethasone) via the electrospinning process. The antibacterial activity and fast disintegration properties of the JFP/pullulan textiles indicated their potential applications for fast-dissolving drug delivery systems. Feng et al. [76] reported electrospun core-shell nanofibers consisting of the outer shell layer of sodium alginate and the inner core composed of salmon calcitonin (sCT)-loaded liposome coated with pectin to be used for colon-targeted drug delivery. An in vitro study demonstrated that the encapsulated $\mathrm{sCT}$ was released in a sustained and colon-targeted way. In addition, the core-shell nanofibrous textiles were more efficient than the uniaxial one in eliminating the burst release of encapsulated drugs. Yang et al. [77] reported the electrospinning of guar gum solutions loaded with tannic acid (a natural phenolic compound derived from fruits and plants known as an antioxidant), anticarcinogenic, and antimicrobial agents to fabricate nanofibrous textiles as drug delivery scaffolds.

\subsection{Tissue Engineering}

Tissue engineering is a regenerative technique that implies the in vitro reconstruction of tissues and the transplantation of the constructs to the sites where tissues need to be regenerated in vivo. For this technique, the development of artificial cellular scaffolds that mimic ECM is of great interest. The electrospinning technique is able to produce nanoscale fiber mats with high porosity, low density, and proper mechanical strength similar to native tissue ECM. Furthermore, electrospinning allows effective incorporation of biologically active substances, both entrapped or covalently bound with the fiber, which significantly increases the tissue healing potential of nanofibrous textiles [9]. Many electrospun polysaccharidic textiles have a similar structure to the natural components of ECM and are being used for tissue engineering because they are nontoxic, biocompatible, and biodegradable. Chemical modifications of polysaccharides with biologically active groups, as well as other functional groups, could improve the properties of the spinning solutions, e.g., solubility and viscoelasticity, and the mechanical properties of their electrospun textiles. Figure 5 illustrates the tissue engineering on electrospun nonwoven textiles made of nonaligned and aligned polysaccharidic nanofibers.

Stem cells are frequently used to determine cell compatibility. These cells are able to differentiate to various cell types and, thus, the applicability of the textiles for large-scale tissue engineering scaffolds could be assessed with them. The cytocompatibility of chitosanand chitin-based textiles using stem cells have been demonstrated. Shalumon et al. [78] reported that human mesenchymal stem cells were able to attach and spread in scaffolds made of carboxymethyl chitin/PVA composite electrospun nanofibers that were crosslinked under glutaraldehyde vapors by heating. In addition, the scaffolds were able to form hydroxyapatite deposits during an in vitro mineralization process. Kang et al. [79] produced electrospun chitosan microfiber mats that can support the attachment and viability of rat muscle-derived stem cells as a biocompatible scaffold in vivo, although the macrophage accumulation was decreased when the cell-embedded textile was subcutaneously implanted due to immunosuppression of the transplanted cells. Nesti et al. [80] 
developed a novel biphasic construct that consisted of an electrospun poly(L-lactic acid) biodegradable nanofibrous scaffold enveloping a hyaluronic acid hydrogel to mimic the microarchitecture of a native intervertebral disc. Multipotent adult human mesenchymal stem cells were then loaded onto the nanofibrous scaffold by injection into the center of the nanofibers. The seeded cells were induced to undergo chondrogenesis in vitro in the presence of transforming growth factor- $\beta$ for up to 28 days. During that period, the microarchitecture of a native intervertebral disc was maintained.

(a) Non-aligned nanofibrous scaffold

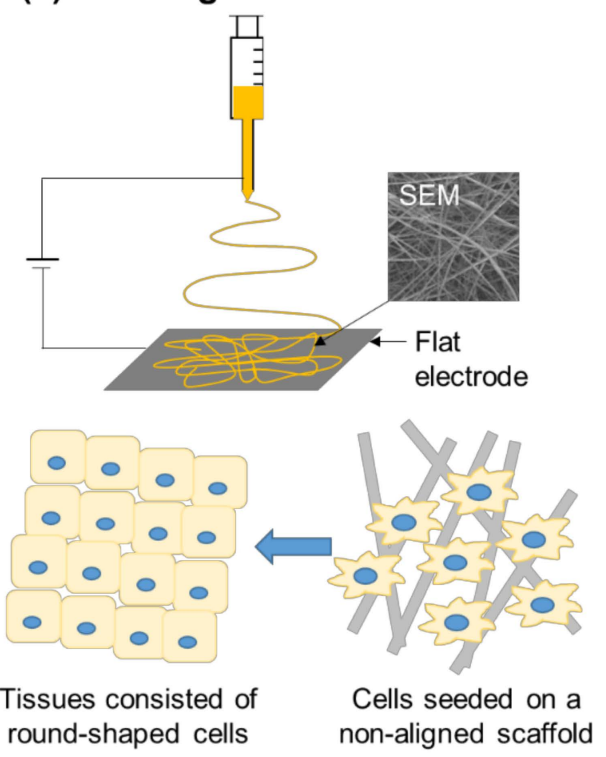

(b) Aligned nanofibrous scaffold
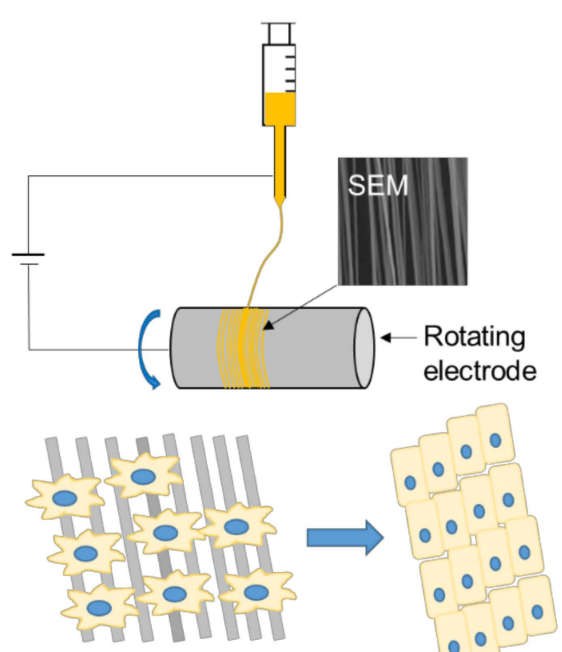

Cells seeded on an aligned scaffold

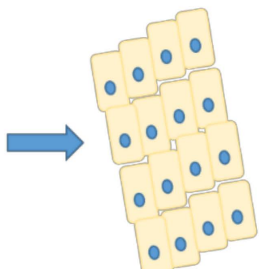

Tissues consisted of spindle-shaped cells

Figure 5. Schematic illustrations of tissue engineering on (a) an electrospun nonaligned nanofibrous scaffold and (b) an aligned electrospun nanofibrous scaffold. In general, cells grow with a rounded morphology on nonaligned fibers, while they grow with a spindle-shaped morphology on aligned fibers [81].

Regeneration of the bone tissue requires higher mechanical properties of the scaffolds, as well as mineral inclusions (Figure 6). Chakraborty et al. [82] proposed regenerated cellulose acetate electrospun membranes for adhesion and proliferation of osteoblast cells in vitro. Chahal et al. [83] demonstrated favorable attachment, spreading, and proliferation of human osteosarcoma cells on the hydroxyethyl cellulose/PVA nanofibrous scaffolds. Furthermore, the hydroxyethyl cellulose moiety was functionalized with a deposited mineral phase, i.e., a mixture of calcium phosphate hydrate and apatite similar to natural bone calcium phosphate. The tensile strength and elastic modulus of the coated scaffolds were comparable to those of femoral bones [84]. Pant et al. [85] were able to increase the osteoblast compatibility and bone formation ability of nylon-6 electrospun scaffolds via the deposition of a chitin butyrate layer on the surface of the nanofibers. Jeong et al. [86] produced electrospun polyelectrolyte complex scaffolds consisting of chitosan and sodium alginate, which were insoluble in water due to electrostatic interactions, allowing the removal of the PEO component that was co-electrospun with the polysaccharides by washing the textiles with water. These scaffolds exhibit increased mouse calvarial preosteoblast adhesion and proliferation compared to those made of alginate alone due to the presence of chitosan, which promotes the adsorption of serum proteins, while alginate is naturally nonadhesive to cells. Petrova et al. $[87,88]$ showed that the addition of the second electrospun layer of polyanion (hyaluronic acid or sodium alginate) on the freshly electrospun chitosan nanofibers induced the polyelectrolyte interaction that resulted in insoluble matrices with enhanced mechanical properties and good cytocompatibility with mesenchymal stem cells. 


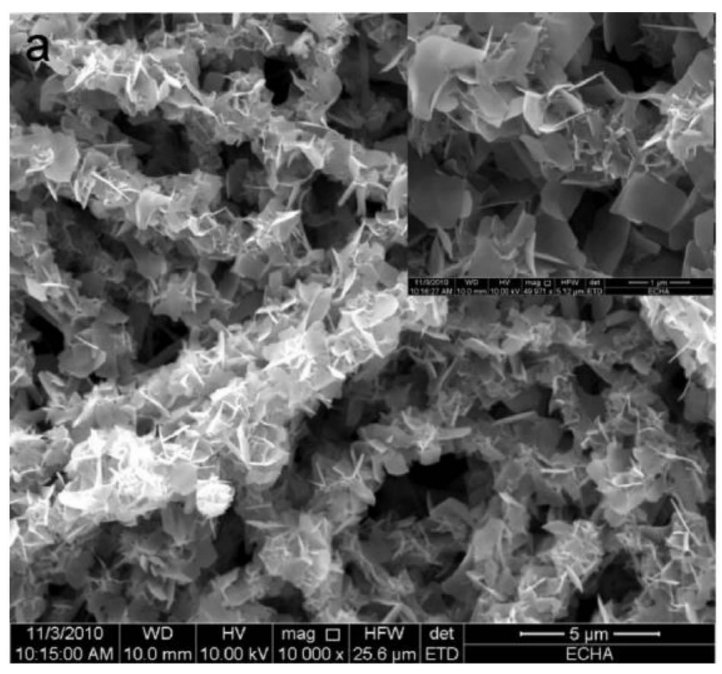

Figure 6. Surface of an electrospun cellulose scaffold mineralized in phosphate buffer saline for 1 week. Inset images reveal the higher magnification of the flake-like, high-surface-area, Ca-P minerals. Adapted with permission form ref. [89]. Copyright 2012 Elsevier.

Polysaccharide electrospun scaffolds have been intensively used to determine in vivo effects on calvaria bone defect models. Zhang et al. [90] prepared aligned cellulose/cellulose nanocrystals nanocomposite scaffolds loaded with bone morphogenic protein BMP-2 with good biological compatibility via electrospinning. The bone human mesenchymal stem cells grew following the underlying aligned nanofibrous scaffolds in vitro accompanied with increased alkaline phosphatase activity and calcium content. The same scaffolds induced aligned collagen assembly and cortical bone formation in an in vivo rabbit calvaria bone defect model. Zhao et al. [91] used carboxymethyl chitosan, a water-soluble derivative of chitosan with better biodegradability and bioactivity, to chelate the $\mathrm{Ca}^{2+}$ cation and induce the deposition of hydroxyapatite. The composite electrospun nanofibers composed of carboxymethyl chitosan and PEO were able to promote the osteogenic differentiation of mouse bone marrow stromal cells in vitro, as well as to increase the alkaline phosphatase activity. The scaffolds containing hydroxyapatite increased the gene expression level compared to pure carboxymethyl chitosan. Thus, the level of osteogenic-specific genes increased by 24 times in 14 days and by 1.5 times in 21 days, showing the role of mineralization at the early stages of bone tissue recovery. Furthermore, in vivo application of the composite fibers allowed the covering of the whole rat calvarial bone defect by new bone in 12 weeks.

Electrospun textiles based on chitin and hyaluronic acid are promising scaffolds for cartilage repair thanks to their similarity to natural cartilage polysaccharides. Chen et al. [92] encapsulated chitin-derived glucosamine sulfate into the core of PCL nanofibers via coaxial electrospinning, and they demonstrated the proliferation and growth of rat articular chondrocytes by cell incubation experiments on the nanofibrous textiles. Khatami et al. [93] functionalized hyaluronic acid via acetylation to make it electrospinnable with PCL in highly polar dimethyl sulfoxide that is suitable for electrospinning. Human mesenchymal stem cells culture experiments on the constructed nanofibrous scaffolds demonstrated an increase in cartilage-specific markers of chondrogenic differentiation. Acetylated hyaluronic acid acted synergically with the differentiation medium on enhancing the expression of glycosaminoglycans, as well as cellular attachment. Nonwovens based on hyaluronic acid were successfully applied to prevent peritendinous surgery adhesions. Chen et al. [94] embedded silver nanoparticles in coaxially electrospun hyaluronic acid core/PCL sheath nanofibers. In vitro cell culture experiments on the electrospun textiles revealed that hyaluronic acid provides effective lubrication, and the microporous structure of nanofibers effectively block the penetration of adhesion-forming fibroblasts. The release of silver nanoparticles from nanofibers provided a short-term anti-bacterial effect during first 4 days, 
while the release of hyaluronic acid lasted up to 21 days. In vivo studies with a rabbit flexor tendon model further confirmed the efficacy of the composite nanofibrous scaffolds in reducing peritendinous adhesion.

For nerve regeneration using electrospun textiles, conductive molecules were coelectrospun with polysaccharides or coated on polysaccharidic scaffolds to improve their conductivity for better performances. Zha et al. [95] covered electrospun cellulose with poly $N$-vinylpyrrole and poly(3-hexylthiophene) through an efficient in situ polymerization, and they found increased thickness, porosity, conductivity, and hydrophilicity of the covered scaffolds. In vitro, undifferentiated PC12 cells showed favorable activity and adhesion to the scaffolds. Electrical stimulation experiments indicated that the fibers covered with poly(3-hexylthiophene) were more effective in the promotion of cell proliferation. Thunberg et al. [96] prepared cellulose nanofibers via the electrospinning of cellulose acetate followed by deacetylation, and they modified their surface via in situ pyrrole polymerization. Polypyrrole was shown to adhere to the cellulose surface as small particles and to greatly increase the scaffold conductivity. In vitro culturing of human neuroblastoma cells indicated the nontoxicity of the composite scaffold and the good cell adhesion on it. The cells adhered to the polypyrrole-coated cellulose altered their morphology to a more neuron-like phenotype. Sadeghi et al. [97] reported that electrospun PCL/chitosan/polypyrrole composite scaffolds were significantly more effective in PC12 cell attachment, spreading, proliferation, and neurite extension compared to a pure PCL scaffold.

For vascular tissue engineering, a nanofibrous textile with tubular shape was prepared by electrospinning using rotating cylinder electrodes with small diameters. Joy et al. [98] prepared the tubular scaffold via electrospinning of the in situ cross-linked hydrogel of gelatin and partially oxidized carboxymethyl cellulose. The tubular scaffolds did not induce a pathological reaction in rats after subcutaneous implantation. Zhang et al. [99] electrospun silk fibroin blended with hyaluronic acid in water at different volume ratios to fabricate nonwoven textiles consisting of ribbon-shaped nanofibers. The structure of the silk fibroin in the textiles was converted from random coils to $\beta$-sheets by a treatment with $75 \%$ ethanol vapor, which made the textiles water-insoluble. Cell viability studies demonstrated that the nanofibrous scaffolds significantly promote proliferation of pig iliac endothelial cells.

\subsection{Wound Healing}

Wound healing is a complicated multistage process that implies cell migration and proliferation for the remodeling of tissues (Figure 7). Wound dressings providing proper $\mathrm{pH}$, humidity, oxygen pressure, and protection against microbial invasion can speed up the wound healing process. Timely and effective wound treatment, including different chronic wounds, is of great significance in modern medicine. Polysaccharides in the form of hydrogel-based wound dressings are considered to be one of the most effective methods for wound treatment due to their desirable biocompatibility and physical characteristics $[100,101]$. Besides, polysaccharide-based electrospun matrices have many advantages in wound healing applications as they are easy to use, could be easily removed from the wound due to limited adhesion, and their porous networks may absorb up to thousands of times their dry weight. All these features can create beneficial microenvironments for wound healing. 

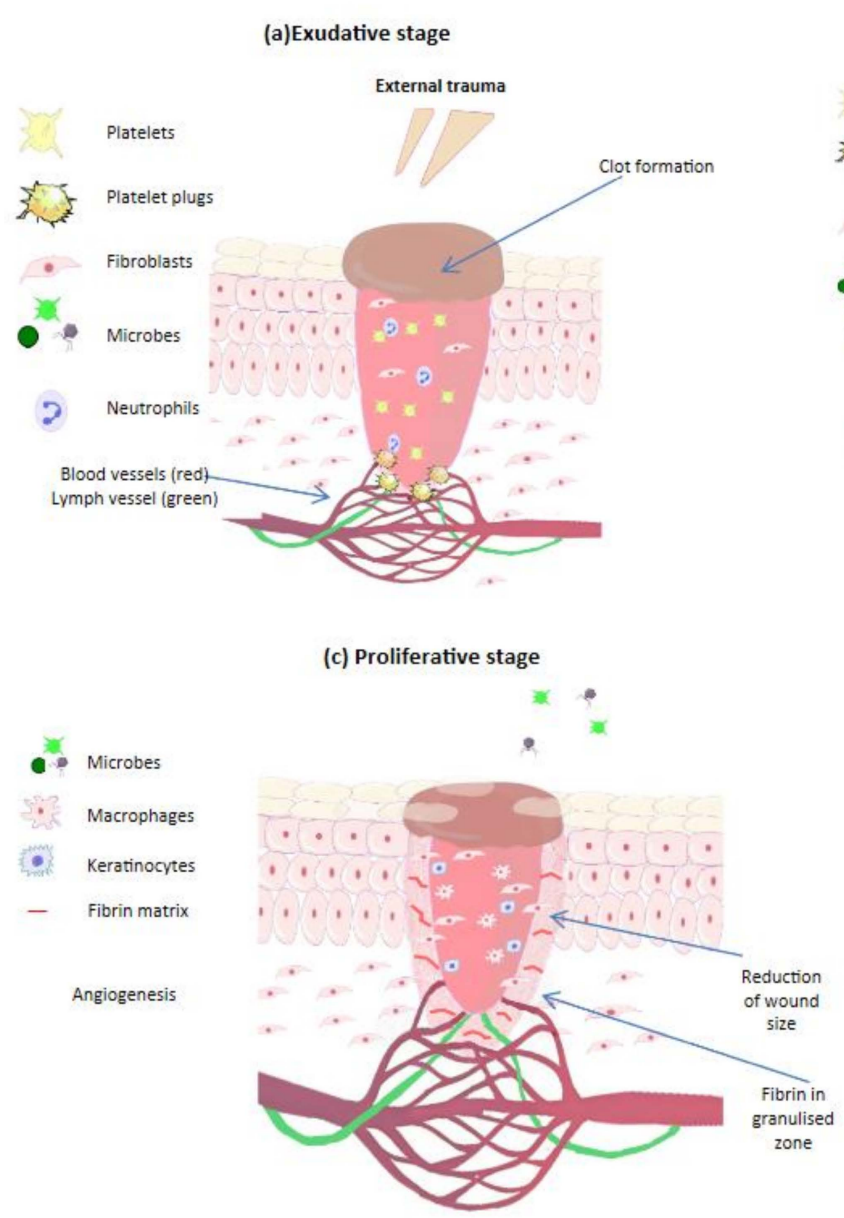

(b) Inflammatory stage

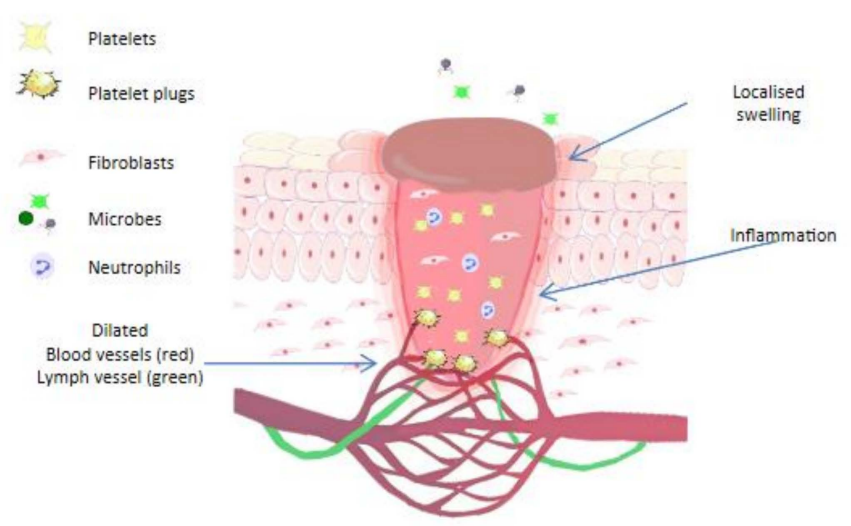

(d) Regenerative stage

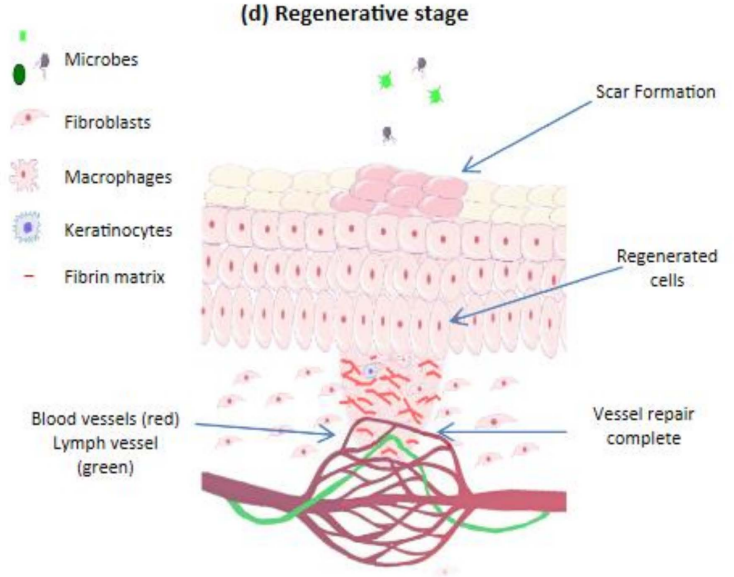

Figure 7. Illustration of the stages of wound healing: (a) exudative stage with the formation of a blood clot, (b) inflammatory stage, marked with edema, pain, and inflammation, (c) proliferation stage with granulation tissue formation, and (d) regenerative stage, characterized by scar tissue formation. Reprinted with permission from ref. [102]. Copyright 2018 Elsevier.

A lot of scaffolds proposed for skin repair have been assessed in vitro using fibroblasts and keratinocytes. Nosar et al. [103] reported that cellulose acetate scaffolds fabricated by wet electrospinning provide nontoxic environments for mouse fibroblast cell cultures and enhance the attachment and proliferation of the cells. As the hydrophobic nature of cellulose acetate is not favorable for cell proliferation, the control of hydrophobicity was expected to be the key to promote tissue regeneration and biodegradation of the nanofibers [104]. Tan et al. [105] succeeded in decreasing the hydrophobicity of cellulose acetate butyrate-based nanofibers by introducing PEG via co-electrospinning. The PEG moiety significantly reduced the water contact angle of the nanofibrous textiles due to the presence of polar hydroxyl groups [106]. The swelling ability of the textiles increased by two-fold accompanied with the more rapid biodegradation and better cell attachment. The textiles were nontoxic for normal human dermal fibroblasts. Atila et al. [107] used pullulan to prepare 3D-electrospun cellulose acetate-based textiles with adjustable thickness. Pullulan was removed by washing the textiles in phosphate-buffered saline (PBS) to increase the porosity, biostability, and mechanical strength of the scaffolds. In vitro cell culture tests showed that the mouse fibroblastic cell line effectively adhered, proliferated, and populated in the textiles made from a cellulose acetate/pullulan (50/50) mixture. Cellulose-based dressings have demonstrated significant healing effects in vivo, including the healing of diabetic ulcers. Samadian et al. [108] incorporated hydroxyapatite in cellulose acetate/gelatin electrospun textiles to improve their performance as wound dressings. The hydroxyapatite content directly influenced the porosity, hydrophilicity, water sorption, 
and vapor transmission rate of the textiles. In vivo, the textiles had higher rat full-thickness excision wound closures than the control sterile gauze did. The highest wound closure value of $93.5 \%$ was achieved with a medium hydroxyapatite content. The dressing with the textiles provided effective collagen synthesis, tissue re-epithelialization, and neovascularization, as well as good cosmetic appearance. Furthermore, the incorporation of berberine, a natural alkaloid found in various plants known for anti-diabetic, antimicrobial, and anti-inflammatory activities, into the textiles improved the biological activities as a diabetic foot ulcer wound dressing [109]. Another cellulose-based dressing exhibited antibacterial activity and provided a proper wound healing in animal studies. Madub et al. [110] extracted cellulose together with ulvan from green seaweeds and electrospun them with PLA and polydioxanone into nanofibrous textiles. These cellulose-based scaffolds showed accelerated fibroblast growth in vitro and demonstrated the absence of a foreign body response and enhanced angiogenesis in a rat wound model.

Chitosan in composition with other polymers can provide intense healing effects. Pezeshki-Modaress et al. [111] reported that chitosan/gelatin electrospun scaffolds increase attachment and proliferation of human dermal fibroblast cells displaying specific spindle-like shapes and stretching. The fibrous morphologies of the scaffolds in the culture medium were maintained for 7 days. The authors showed the positive effect of chitosan content (up to $30 \%$ ) on cell proliferation, as well as the beneficial effect of the nanofibrous structure on the biocompatibility by comparing the performance of a cast film made from the same composition of chitosan/gelatin. Similarly, chitosan in composition with PCL also improved the cell affinity and biocompatibility [112]. Prasad et al. [113] fabricated chitosan/PCL electrospun scaffolds, which revealed enhanced cell adhesion, spreading, and proliferation of mouse fibroblast and human keratinocytes cell lines compared to the scaffolds made of PCL without chitosan. Gomes et al. [114] compared PCL-, gelatin-, and chitosan-based electrospun scaffolds in terms of cell-scaffold interaction and wound healing promotion. In vitro cell viability tests showed that cells were able to penetrate deeply only into the PCL- and chitosan-based scaffolds, while fibroblasts adhered and proliferated well in all scaffolds. In vivo wound healing tests showed that the chitosan-based scaffold had the highest impact on the healing process in a rat wound model with total skin removal by decreasing wound contraction, increasing re-epithelialization, and enhancing neodermis production.

Other polysaccharides and their derivatives such as chitin, hyaluronic acid, and alginate were electrospun, and their nonwoven textiles were also investigated for wound healing applications. Noh et al. [115] evaluated the effect of chitin fiber diameter on biological performance using electrospun nanofibers with a mean diameter of $163 \mathrm{~nm}$ and commercially available microfibers with a mean diameter of $8.77 \mu \mathrm{m}$. The in vitro degradation rate of chitin nanofibers was faster than that of commercial microfibers likely due to their higher surface area. Subcutaneous implantation in rats revealed the almost complete degradation of nanofibers within 28 days with no inflammation in the surrounding tissues. Normal human keratinocytes and fibroblasts spread more intensively on the nanofibers compared to the microfibers. Min et al. [116] coated commercial chitin microfibers with a cell attachment peptide (a laminin-5-derived peptide: Ln5-P4) to increase their efficiency in vivo. The peptide implementation significantly promoted early-stage wound healing in both rat and rabbit full-thickness cutaneous wound models by improving reepithelialization, cell infiltration, and proliferation. The same group [117] also reported that chitin nanoparticles embedded within a PLGA nanofiber matrix $(80 / 20, w / w)$ increased the adhesion and spreading of normal human keratinocytes. Ji et al. [118] chemically modified hyaluronic acid with thiol groups in order to cross-link its electrospun nanofiber network using a bifunctional cross-linker, poly(ethylene glycol) diacrylate. After cross-linking, PEO used to facilitate electrospinning as a viscosity modifier could be selectively washed out with water from the nanofibrous scaffold. A cell morphology study showed that NIH 3T3 fibroblasts effectively attached and spread on the scaffold, demonstrating an extended 3D dendritic morphology [119]. Jeong et al. [120] greatly enhanced the ability of electrospun 
alginate scaffolds to support the attachment, spreading, and proliferation of human dermal fibroblast via modification of the scaffolds with a cell-adhesive peptide (GRGDSP). Ma et al. [121] prepared core-shell structured nanofibers of sodium alginate/PEO crosslinked with $\mathrm{CaCl}_{2}$. The fibers were nontoxic to the fibroblasts and tended to promote cells attachment and proliferation.

Anti-infection properties of dressings play an important role in wound healing applications. Antimicrobial properties could be improved using chitosan-quaternized derivatives that exhibited good performances against a wide range of bacteria [122]. Introducing different antibiotics and antimicrobials such as zinc oxide $(\mathrm{ZnO})$ and silver nanoparticles (AgNPs) has been shown to effectively increase the antibacterial effectiveness of electrospun textiles. An et al. [123] effectively distributed ultrafine $(<5 \mathrm{~nm})$ AgNPs in chitosan/PEO nanofibers via electrospinning. The AgNPs-embedded nanofibers had a significantly enhanced antibacterial activity against Escherichia coli compared to fibers without AgNPs. Hadisi et al. [124] proposed a novel wound dressing made of core-shell nanofibers composed of $\mathrm{ZnO}$-dispersed silk fibroin as the core and hyaluronic acid as the shell for treatments of burn injuries. The loading of $\mathrm{ZnO}$ in the core of the nanofibers enabled its sustained release and improved the antibacterial property of the dressing against Escherichia coli and Staphylococcus aureus in a dose-dependent manner. In vivo studies in a rat second-degree burn model indicated that the wound dressing loaded with $\mathrm{ZnO}$ $(3 \mathrm{wt} \%)$ substantially improves the wound healing procedure and significantly reduces the inflammatory response at the wound site, while concentrations of $\mathrm{ZnO}$ more than $3 \mathrm{wt} \%$ were shown to be toxic to the cells in vitro. Dodero et al. [125] reported that $\mathrm{ZnO}$ nanoparticles incorporated in alginate-based electrospun textiles provide strong anti-bacteriostatic and anti-bacterial properties without showing toxicity to fibroblasts and keratinocytes. Song et al. [126] prepared chitosan/PEO nanofibrous textiles by electrospinning for dual releases of chlorhexidine and Ag ions. The membrane exhibited a fast release of chlorhexidine in 2 days and a sustained release of Ag ions for up to 28 days, effectively inactivating Staphylococcus aureus.

Antibiotics-loaded nanofibers can be applied not only for skin healing but also for post-operation implants such as the prevention of abdominal adhesion and prophylaxis of infections in orthopedic surgery [127]. Alavarse et al. [128] prepared PVA/chitosanbased wound dressings containing tetracycline hydrochloride via electrospinning. The drug-loaded dressings showed good cytocompatibility and effective antibacterial activity in vitro by a burst drug release within $2 \mathrm{~h}$ in PBS. Ahire et al. [129] reported that kanamycin-loaded hyaluronic acid/PEO-based electrospun textiles inhibited the growth of Listeria monocytogenes by $62 \%$ compared to textiles without the antibiotic. Amiri et al. [130] reported that teicoplanin-loaded chitosan/PEO-based electrospun textiles showed sustained releases of the antibiotic in vitro up to 12 days, and their antibacterial activities were 1.5 to 2 times higher than that of free teicoplanin. The textiles showed no cytotoxicity to human fibroblasts and demonstrated better wound closure in a rat full thickness wound model. Khan et al. [131] reported that tinidazole-loaded chitosan/PCL-based electrospun textiles showed sustained release of the antibiotic in vitro up to 18 days, inhibiting bacterial growth without any toxic effect on mouse fibroblasts. Yang et al. [132] incorporated ciprofloxacin into chitosan/graphene oxide/PVA composite nanofibrous textiles via electrospinning. The textiles showed significant antibacterial activities while exhibiting excellent cytocompatibilities with melanoma cells. Part of the ciprofloxacin in the textiles was absorbed into the graphene oxide moiety, avoiding burst releases of the antibiotics. Fazli et al. [133] reported that electrospun chitosan/PEO-based nanofibrous textiles containing cefazolin and fumed silica demonstrated strong bactericidal activities, while the presence of silica slowed down burst releases of cefazolin. Dressings made of the textiles almost entirely healed wounded skins of female rats in vivo within 10 days. Chuysinuan et al. [134] developed core-shell nanofibers composed of tetracycline, alginate, and a soy protein isolate as the core and PCL as the shell by means of coaxial electrospinning. In vitro, the core-shell nanofibrous textile exhibited dual release profiles with an 
initial burst release of $50 \%$ of the total loaded antibiotics within $6 \mathrm{~h}$ and a sustained release up to $80 \%$ in 2 weeks. The textile provided high viability with human dermal fibroblasts and demonstrated good antibacterial properties.

\section{Conclusions}

Despite the technical difficulties and challenges in the electrospinning of polysaccharides and their derivatives, the number of publications concerning this innovative research topic has been constantly growing. Electrospun polysaccharidic textiles have been spotlighted as a promising scaffold for various biomedical clinical applications thanks to the superior structural properties of nanofibrous textiles and the natural properties of polysaccharides. The electrospinning technique has made it possible to produce multifunctional composite textiles, including those embedding bioactive substances to improve their biocompatibility/-degradability/-availability and minerals for their structural reinforcements. Electrospun polysaccharidic textiles have been shown to be effective molecular delivery agents with controllable release properties. Fine structures of electrospun nanofibers and their nonwoven textiles allow tuning release rates and profiles by altering the fiber diameter, architecture, porosity, etc. It has been demonstrated that electrospun textiles based on polysaccharides can stimulate new tissue growth, re-epithelization, revascularization, as well as cell differentiation, making them highly efficient in wound healing and tissue engineering applications. At the same time, many questions remain open. The main concern is the effect of the chemical composition and 3D structure of polysaccharidic textiles on cell growth. As polysaccharides are bioactive and have been shown to support good cell attachment and proliferation, it is our opinion that further scaffold development is central to a better understanding of cell-scaffold interactions and the structural features determining cell infiltration and migration. Further in vivo experiments will shed light on the mechanism of cell-scaffold interactions, which enable proper clinical applications of electrospun polysaccharidic textiles.

Author Contributions: Conceptualization, I.O.; writing, D.P. and I.O.; editing, I.O. All authors have read and agreed to the published version of the manuscript.

Funding: This research was funded by the Russian Foundation for Basic Research (18-29-17074) to D.P. and Institut Carnot PolyNat (ANR-16-CARN-0025-0) to I.O.

Institutional Review Board Statement: Not applicable.

Informed Consent Statement: Not applicable.

Data Availability Statement: The data shown in Figure 2 were analyzed by using SciFinder-n software available at https:/ / scifinder-n.cas.org accessed on 20 April 2021.

Acknowledgments: The authors are grateful to Robert Pecora at Stanford University (https:// chemistry.stanford.edu/people/robert-pecora) for his helpful suggestions during the writing of this manuscript. The authors also thank the Metchnikov program of the Embassy of France in the Russian Federation that facilitates the mobility of researchers that has provided the opportunity for the scientific collaboration between D.P. and I.O.

Conflicts of Interest: The authors declare no conflict of interest.

\section{References}

1. Huang, Z.-M.; Zhang, Y.Z.; Kotaki, M.; Ramakrishna, S. A review on polymer nanofibers by electrospinning and their applications in nanocomposites. Compos. Sci. Technol. 2003, 63, 2223-2253. [CrossRef]

2. Li, D.; Xia, Y. Electrospinning of nanofibers: Reinventing the wheel? Adv. Mater. 2004, 16, 1151-1170. [CrossRef]

3. Greiner, A.; Wendorff, J.H. Electrospinning: A fascinating method for the preparation of ultrathin fibers. Angew. Chem. Int. Ed. 2007, 46, 5670-5703. [CrossRef] [PubMed]

4. Bhardwaj, N.; Kundu, S.C. Electrospinning: A fascinating fiber fabrication technique. Biotechnol. Adv. 2010, $28,325-347$. [CrossRef] [PubMed]

5. Agarwal, S.; Wendorff, J.H.; Greiner, A. Use of electrospinning technique for biomedical applications. Polymer 2008, 49, 5603-5621. [CrossRef] 
6. Meinel, A.J.; Germershaus, O.; Luhmann, T.; Merkle, H.P.; Meinel, L. Electrospun matrices for localized drug delivery: Current technologies and selected biomedical applications. Eur. J. Pharm. Biopharm. 2012, 81, 1-13. [CrossRef] [PubMed]

7. Sill, T.J.; von Recum, H.A. Electrospinning: Applications in drug delivery and tissue engineering. Biomaterials 2008, 29, 1989-2006. [CrossRef] [PubMed]

8. Balaji, A.; Vellayappan, M.V.; John, A.A.; Subramanian, A.P.; Jaganathan, S.K.; Supriyanto, E.; Razak, S.I.A. An insight on electrospun-nanofibers-inspired modern drug delivery system in the treatment of deadly cancers. RSC Adv. 2015, 5, 57984-58004. [CrossRef]

9. Agarwal, S.; Wendorff, J.H.; Greiner, A. Progress in the field of electrospinning for tissue engineering applications. Adv. Mater. 2009, 21, 3343-3351. [CrossRef]

10. Martins, A.; Reis, R.L.; Neves, N.M. Electrospinning: Processing technique for tissue engineering scaffolding. Int. Mater. Rev. 2008, 53, 257-274. [CrossRef]

11. Zahedi, P.; Rezaeian, I.; Ranaei-Siadat, S.-O.; Jafari, S.-H.; Supaphol, P. A review on wound dressings with an emphasis on electrospun nanofibrous polymeric bandages. Polym. Adv. Technol. 2010, 21, 77-95. [CrossRef]

12. Zhong, S.P.; Zhang, Y.Z.; Lim, C.T. Tissue scaffolds for skin wound healing and dermal reconstruction. Wiley Interdiscip. Rev. Nanomed. Nanobiotechnol. 2010, 2, 510-525. [CrossRef] [PubMed]

13. Rieger, K.A.; Birch, N.P.; Schiffman, J.D. Designing electrospun nanofiber mats to promote wound healing-A review. J. Mater. Chem. B 2013, 1, 4531-4541. [CrossRef] [PubMed]

14. Chen, S.; Li, R.; Li, X.; Xie, J. Electrospinning: An enabling nanotechnology platform for drug delivery and regenerative medicine. Adv. Drug Deliv. Rev. 2018, 132, 188-213. [CrossRef]

15. Shahriar, S.M.S.; Mondal, J.; Hasan, M.N.; Revuri, V.; Lee, D.Y.; Lee, Y.-K. Electrospinning nanofibers for therapeutics delivery. Nanomaterials 2019, 9, 532. [CrossRef]

16. Zhang, M.; Zhao, X.; Zhang, G.; Wei, G.; Su, Z. Electrospinning design of functional nanostructures for biosensor applications. J. Mater. Chem. B 2017, 5, 1699-1711. [CrossRef]

17. De Sio, L.; Ding, B.; Focsan, M.; Kogermann, K.; Pascoal-Faria, P.; Petronela, F.; Mitchell, G.; Zussman, E.; Pierini, F. Personalized reusable face masks with smart nano-assisted destruction of pathogens for COVID-19: A visionary road. Chem. A Eur. J. 2021, 27, 6112-6130. [CrossRef]

18. Schiffman, J.D.; Schauer, C.L. A review: Electrospinning of biopolymer nanofibers and their applications. Polym. Rev. 2008, 48, 317-352. [CrossRef]

19. Sridhar, R.; Lakshminarayanan, R.; Madhaiyan, K.; Amutha Barathi, V.; Lim, K.H.C.; Ramakrishna, S. Electrosprayed nanoparticles and electrospun nanofibers based on natural materials: Applications in tissue regeneration, drug delivery and pharmaceuticals. Chem. Soc. Rev. 2015, 44, 790-814. [CrossRef]

20. Zhao, W.; Liu, W.; Li, J.; Lin, X.; Wang, Y. Preparation of animal polysaccharides nanofibers by electrospinning and their potential biomedical applications. J. Biomed. Mater. Res. Part A 2015, 103, 807-818. [CrossRef]

21. Ohkawa, K. Nanofibers of cellulose and its derivatives fabricated using direct electrospinning. Molecules 2015, 20, 9139-9154. [CrossRef]

22. Costoya, A.; Concheiro, A.; Alvarez-Lorenzo, C. Electrospun fibers of cyclodextrins and poly(cyclodextrins). Molecules 2017, 22, 230. [CrossRef]

23. Lee, K.Y.; Jeong, L.; Kang, Y.O.; Lee, S.J.; Park, W.H. Electrospinning of polysaccharides for regenerative medicine. Adv. Drug Deliv. Rev. 2009, 61, 1020-1032. [CrossRef]

24. Konwarh, R.; Karak, N.; Misra, M. Electrospun cellulose acetate nanofibers: The present status and gamut of biotechnological applications. Biotechnol. Adv. 2013, 31, 421-437. [CrossRef]

25. Frey, M.W. Electrospinning cellulose and cellulose derivatives. Polym. Rev. 2008, 48, 378-391. [CrossRef]

26. Mendes, A.C.; Stephansen, K.; Chronakis, I.S. Electrospinning of food proteins and polysaccharides. Food Hydrocoll. 2017, 68, 53-68. [CrossRef]

27. Liu, H.; Hsieh, Y.-L. Ultrafine fibrous cellulose membranes from electrospinning of cellulose acetate. J. Polym. Sci. Part B Polym. Phys. 2002, 40, 2119-2129. [CrossRef]

28. Ohkawa, K.; Cha, D.; Kim, H.; Nishida, A.; Yamamoto, H. Electrospinning of chitosan. Macromol. Rapid Commun. 2004, 25, 1600-1605. [CrossRef]

29. Jiang, H.; Fang, D.; Hsiao, B.S.; Chu, B.; Chen, W. Optimization and characterization of dextran membranes prepared by electrospinning. Biomacromolecules 2004, 5, 326-333. [CrossRef]

30. Kulpinski, P. Cellulose nanofibers prepared by the N-methylmorpholine-N-oxide method. J. Appl. Polym. Sci. 2005, 98, 1855-1859. [CrossRef]

31. Kim, C.-W.; Frey, M.W.; Marquez, M.; Joo, Y.L. Preparation of submicron-scale, electrospun cellulose fibers via direct dissolution. J. Polym. Sci. Part B Polym. Phys. 2005, 43, 1673-1683. [CrossRef]

32. Kim, C.-W.; Kim, D.-S.; Kang, S.-Y.; Marquez, M.; Joo, Y.L. Structural studies of electrospun cellulose nanofibers. Polymer 2006, 47, 5097-5107. [CrossRef]

33. Min, B.-M.; Lee, S.W.; Lim, J.N.; You, Y.; Lee, T.S.; Kang, P.H.; Park, W.H. Chitin and chitosan nanofibers: Electrospinning of chitin and deacetylation of chitin nanofibers. Polymer 2004, 45, 7137-7142. [CrossRef] 
34. Ohkawa, K.; Minato, K.-I.; Kumagai, G.; Hayashi, S.; Yamamoto, H. Chitosan nanofiber. Biomacromolecules 2006, 7, $3291-3294$. [CrossRef]

35. Schiffman, J.D.; Schauer, C.L. Cross-linking chitosan nanofibers. Biomacromolecules 2007, 8, 594-601. [CrossRef]

36. Sangsanoh, P.; Supaphol, P. Stability improvement of electrospun chitosan nanofibrous membranes in neutral or weak basic aqueous solutions. Biomacromolecules 2006, 7, 2710-2714. [CrossRef]

37. Otsuka, I.; Njinang, C.N.; Borsali, R. Simple fabrication of cellulose nanofibers via electrospinning of dissolving pulp and tunicate. Cellulose 2017, 24, 3281-3288. [CrossRef]

38. Frenot, A.; Henriksson, M.W.; Walkenström, P. Electrospinning of cellulose-based nanofibers. J. Appl. Polym. Sci. 2007, 103, 1473-1482. [CrossRef]

39. Kriegel, C.; Kit, K.M.; McClements, D.J.; Weiss, J. Electrospinning of chitosan-poly(ethylene oxide) blend nanofibers in the presence of micellar surfactant solutions. Polymer 2009, 50, 189-200. [CrossRef]

40. Lu, J.-W.; Zhu, Y.-L.; Guo, Z.-X.; Hu, P.; Yu, J. Electrospinning of sodium alginate with poly(ethylene oxide). Polymer 2006, 47, 8026-8031. [CrossRef]

41. Bhattarai, N.; Li, Z.; Edmondson, D.; Zhang, M. Alginate-based nanofibrous scaffolds: Structural, mechanical, and biological properties. Adv. Mater. 2006, 18, 1463-1467. [CrossRef]

42. Safi, S.; Morshed, M.; Ravandi, S.A.H.; Ghiaci, M. Study of electrospinning of sodium alginate, blended solutions of sodium alginate/poly(vinyl alcohol) and sodium alginate/poly(ethylene oxide). J. Appl. Polym. Sci. 2007, 104, 3245-3255. [CrossRef]

43. Ding, B.; Kimura, E.; Sato, T.; Fujita, S.; Shiratori, S. Fabrication of blend biodegradable nanofibrous nonwoven mats via multi-jet electrospinning. Polymer 2004, 45, 1895-1902. [CrossRef]

44. Zhang, Y.; Huang, X.; Duan, B.; Wu, L.; Li, S.; Yuan, X. Preparation of electrospun chitosan/poly(vinyl alcohol) membranes. Colloid Polym. Sci. 2007, 285, 855-863. [CrossRef]

45. Xu, J.; Zhang, J.; Gao, W.; Liang, H.; Wang, H.; Li, J. Preparation of chitosan/PLA blend micro/nanofibers by electrospinning. Mater. Lett. 2009, 63, 658-660. [CrossRef]

46. Shalumon, K.T.; Anulekha, K.H.; Girish, C.M.; Prasanth, R.; Nair, S.V.; Jayakumar, R. Single step electrospinning of chitosan/poly(caprolactone) nanofibers using formic acid/acetone solvent mixture. Carbohydr. Polym. 2010, 80, 413-419. [CrossRef]

47. Park, W.H.; Jeong, L.; Yoo, D.I.; Hudson, S. Effect of chitosan on morphology and conformation of electrospun silk fibroin nanofibers. Polymer 2004, 45, 7151-7157. [CrossRef]

48. Torres-Giner, S.; Ocio, M.J.; Lagaron, J.M. Novel antimicrobial ultrathin structures of zein/chitosan blends obtained by electrospinning. Carbohydr. Polym. 2009, 77, 261-266. [CrossRef]

49. Chen, Z.; Mo, X.; Qing, F. Electrospinning of collagen-chitosan complex. Mater. Lett. 2007, 61, 3490-3494. [CrossRef]

50. Chee, B.S.; Nugent, M. Chapter 26-Electrospun natural polysaccharide for biomedical application. In Natural Polysaccharides in Drug Delivery and Biomedical Applications; Hasnain, M.S., Nayak, A.K., Eds.; Academic Press: Cambridge, MA, USA, 2019; pp. 589-615.

51. Otsuka, I.; Borsali, R. Electrospun biomaterials. In Bioelectrochemistry, Design and Applications of Biomaterials; Cosnier, S., Ed.; De Gruyter: Berlin, Germany; Boston, MD, USA, 2019; pp. 45-58.

52. Wsoo, M.A.; Shahir, S.; Mohd Bohari, S.P.; Nayan, N.H.M.; Razak, S.I.A. A review on the properties of electrospun cellulose acetate and its application in drug delivery systems: A new perspective. Carbohydr. Res. 2020, 491, 107978. [CrossRef]

53. Khoshnevisan, K.; Maleki, H.; Samadian, H.; Shahsavari, S.; Sarrafzadeh, M.H.; Larijani, B.; Dorkoosh, F.A.; Haghpanah, V.; Khorramizadeh, M.R. Cellulose acetate electrospun nanofibers for drug delivery systems: Applications and recent advances. Carbohydr. Polym. 2018, 198, 131-141. [CrossRef]

54. Tungprapa, S.; Jangchud, I.; Supaphol, P. Release characteristics of four model drugs from drug-loaded electrospun cellulose acetate fiber mats. Polymer 2007, 48, 5030-5041. [CrossRef]

55. Yang, Y.; Li, W.; Yu, D.-G.; Wang, G.; Williams, G.R.; Zhang, Z. Tunable drug release from nanofibers coated with blank cellulose acetate layers fabricated using tri-axial electrospinning. Carbohydr. Polym. 2019, 203, 228-237. [CrossRef]

56. Yu, D.-G.; Yu, J.-H.; Chen, L.; Williams, G.R.; Wang, X. Modified coaxial electrospinning for the preparation of high-quality ketoprofen-loaded cellulose acetate nanofibers. Carbohydr. Polym. 2012, 90, 1016-1023. [CrossRef]

57. Yu, D.-G.; Li, X.-Y.; Wang, X.; Chian, W.; Liao, Y.-Z.; Li, Y. Zero-order drug release cellulose acetate nanofibers prepared using coaxial electrospinning. Cellulose 2013, 20, 379-389. [CrossRef]

58. Chung, J.; Kwak, S.-Y. Effect of nanoscale confinement on molecular mobility and drug release properties of cellulose acetate/sulindac nanofibers. J. Appl. Polym. Sci. 2019, 136, 47863. [CrossRef]

59. Absar, S.; Khan, M.; Edwards, K.; Neumann, J. Investigation of synthesis and processing of cellulose, cellulose acetate and poly(ethylene oxide) nanofibers incorporating anti-cancer/tumor drug cis-diammineplatinum(II) dichloride using electrospinning techniques. J. Polym. Eng. 2015, 35, 867-878. [CrossRef]

60. Phiriyawirut, M.; Phaechamud, T. Cellulose acetate electrospun fiber mats for controlled release of silymarin. J. Nanosci. Nanotechnol. 2012, 12, 793-799. [CrossRef]

61. Khor, E.; Lim, L.Y. Implantable applications of chitin and chitosan. Biomaterials 2003, 24, 2339-2349. [CrossRef]

62. Jayakumar, R.; Menon, D.; Manzoor, K.; Nair, S.V.; Tamura, H. Biomedical applications of chitin and chitosan based nanomaterialsA short review. Carbohydr. Polym. 2010, 82, 227-232. [CrossRef] 
63. Jayakumar, R.; Prabaharan, M.; Nair, S.V.; Tamura, H. Novel chitin and chitosan nanofibers in biomedical applications. Biotechnol. Adv. 2010, 28, 142-150. [CrossRef] [PubMed]

64. Anitha, A.; Sowmya, S.; Kumar, P.T.S.; Deepthi, S.; Chennazhi, K.P.; Ehrlich, H.; Tsurkan, M.; Jayakumar, R. Chitin and chitosan in selected biomedical applications. Prog. Polym. Sci. 2014, 39, 1644-1667. [CrossRef]

65. Jiang, H.; Fang, D.; Hsiao, B.; Chu, B.; Chen, W. Preparation and characterization of ibuprofen-loaded poly(lactide-coglycolide)/poly(ethylene glycol)-g-chitosan electrospun membranes. J. Biomater. Sci. Polym. Ed. 2004, 15, 279-296. [CrossRef] [PubMed]

66. Faralli, A.; Shekarforoush, E.; Ajalloueian, F.; Mendes, A.C.; Chronakis, I.S. In vitro permeability enhancement of curcumin across Caco-2 cells monolayers using electrospun xanthan-chitosan nanofibers. Carbohydr. Polym. 2019, 206, 38-47. [CrossRef]

67. Rostami, M.; Ghorbani, M.; Aman Mohammadi, M.; Delavar, M.; Tabibiazar, M.; Ramezani, S. Development of resveratrol loaded chitosan-gellan nanofiber as a novel gastrointestinal delivery system. Int. J. Biol. Macromol. 2019, 135, 698-705. [CrossRef]

68. Huang, X.-J.; Ge, D.; Xu, Z.-K. Preparation and characterization of stable chitosan nanofibrous membrane for lipase immobilization. Eur. Polym. J. 2007, 43, 3710-3718. [CrossRef]

69. Burdick, J.A.; Prestwich, G.D. Hyaluronic acid hydrogels for biomedical applications. Adv. Mater. 2011, 23, H41-H56. [CrossRef]

70. Tripodo, G.; Trapani, A.; Torre, M.L.; Giammona, G.; Trapani, G.; Mandracchia, D. Hyaluronic acid and its derivatives in drug delivery and imaging: Recent advances and challenges. Eur. J. Pharm. Biopharm. 2015, 97, 400-416. [CrossRef]

71. Snetkov, P.P.; Sitnikova, V.E.; Uspenskaya, M.V.; Morozkina, S.N.; Olekhnovich, R.O. Hyaluronic Acid-Curcumin electrospun fibers. Russ. Chem. Bull. 2020, 69, 596-600. [CrossRef]

72. Snetkov, P.; Morozkina, S.; Olekhnovich, R.; Vu, T.H.N.; Tyanutova, M.; Uspenskaya, M. Curcumin/Usnic Acid-Loaded electrospun nanofibers based on hyaluronic acid. Materials 2020, 13, 3476. [CrossRef]

73. Agrahari, V.; Meng, J.; Ezoulin, M.J.; Youm, I.; Dim, D.C.; Molteni, A.; Hung, W.-T.; Christenson, L.K.; Youan, B.-B.C. Stimulisensitive thiolated hyaluronic acid based nanofibers: Synthesis, preclinical safety and in vitro anti-HIV activity. Nanomedicine 2016, 11, 2935-2958. [CrossRef]

74. Mascheroni, E.; Fuenmayor, C.A.; Cosio, M.S.; Di Silvestro, G.; Piergiovanni, L.; Mannino, S.; Schiraldi, A. Encapsulation of volatiles in nanofibrous polysaccharide membranes for humidity-triggered release. Carbohydr. Polym. 2013, 98, 17-25. [CrossRef]

75. Ponrasu, T.; Chen, B.-H.; Chou, T.-H.; Wu, J.-J.; Cheng, Y.-S. Fast dissolving electrospun nanofibers fabricated from jelly fig polysaccharide/pullulan for drug delivery applications. Polymers 2021, 13, 241. [CrossRef]

76. Feng, K.; Li, C.; Wei, Y.-S.; Zong, M.-H.; Wu, H.; Han, S.-Y. Development of a polysaccharide based multi-unit nanofiber mat for colon-targeted sustained release of salmon calcitonin. J. Colloid Interface Sci. 2019, 552, 186-195. [CrossRef]

77. Yang, W.; Zhang, M.; Li, X.; Jiang, J.; Sousa, A.M.M.; Zhao, Q.; Pontious, S.; Liu, L. Incorporation of tannic acid in food-grade guar gum fibrous mats by electrospinning technique. Polymers 2019, 11, 141. [CrossRef]

78. Shalumon, K.; Binulal, N.; Selvamurugan, N.; Nair, S.; Menon, D.; Furuike, T.; Tamura, H.; Jayakumar, R. Electrospinning of carboxymethyl chitin/poly (vinyl alcohol) nanofibrous scaffolds for tissue engineering applications. Carbohydr. Polym. 2009, 77, 863-869. [CrossRef]

79. Kang, Y.M.; Lee, B.N.; Ko, J.H.; Kim, G.H.; Kang, K.N.; Kim, D.Y.; Kim, J.H.; Park, Y.H.; Chun, H.J.; Kim, C.H. In vivo biocompatibility study of electrospun chitosan microfiber for tissue engineering. Int. J. Mol. Sci. 2010, 11, 4140-4148. [CrossRef]

80. Nesti, L.J.; Li, W.-J.; Shanti, R.M.; Jiang, Y.J.; Jackson, W.; Freedman, B.A.; Kuklo, T.R.; Giuliani, J.R.; Tuan, R.S. Intervertebral disc tissue engineering using a novel hyaluronic acid-nanofibrous scaffold (HANFS) amalgam. Tissue Eng. Part A 2008, 14, 1527-1537. [CrossRef]

81. Jenkins, T.L.; Little, D. Synthetic scaffolds for musculoskeletal tissue engineering: Cellular responses to fiber parameters. NPJ Regen. Med. 2019, 4, 15. [CrossRef]

82. Chakraborty, P.K.; Adhikari, J.; Saha, P. Facile fabrication of electrospun regenerated cellulose nanofiber scaffold for potential bone-tissue engineering application. Int. J. Biol. Macromol. 2019, 122, 644-652. [CrossRef]

83. Chahal, S.; Hussain, F.S.J.; Kumar, A.; Rasad, M.S.B.A.; Yusoff, M.M. Fabrication, characterization and in vitro biocompatibility of electrospun hydroxyethyl cellulose/poly(vinyl) alcohol nanofibrous composite biomaterial for bone tissue engineering. Chem. Eng. Sci. 2016, 144, 17-29. [CrossRef]

84. Chahal, S.; Hussain, F.S.J.; Kumar, A.; Yusoff, M.M.; Rasad, M.S.B.A. Electrospun hydroxyethyl cellulose nanofibers functionalized with calcium phosphate coating for bone tissue engineering. RSC Adv. 2015, 5, 29497-29504. [CrossRef]

85. Pant, H.R.; Kim, H.J.; Bhatt, L.R.; Joshi, M.K.; Kim, E.K.; Kim, J.I.; Abdal-Hay, A.; Hui, K.; Kim, C.S. Chitin butyrate coated electrospun nylon-6 fibers for biomedical applications. Appl. Surf. Sci. 2013, 285, 538-544. [CrossRef]

86. Jeong, S.I.; Krebs, M.D.; Bonino, C.A.; Samorezov, J.E.; Khan, S.A.; Alsberg, E. Electrospun chitosan-alginate nanofibers with in situ polyelectrolyte complexation for use as tissue engineering scaffolds. Tissue Eng. Part A 2011, 17, 59-70. [CrossRef]

87. Petrova, V.A.; Chernyakov, D.D.; Poshina, D.N.; Gofman, I.V.; Romanov, D.P.; Mishanin, A.I.; Golovkin, A.S.; Skorik, Y.A. Electrospun bilayer chitosan/hyaluronan material and its compatibility with mesenchymal stem cells. Materials 2019, 12, 2016. [CrossRef]

88. Petrova, V.A.; Golovkin, A.S.; Mishanin, A.I.; Romanov, D.P.; Chernyakov, D.D.; Poshina, D.N.; Skorik, Y.A. Cytocompatibility of bilayer scaffolds electrospun from chitosan/alginate-chitin nanowhiskers. Biomedicines 2020, 8, 305. [CrossRef] [PubMed]

89. Rodríguez, K.; Sundberg, J.; Gatenholm, P.; Renneckar, S. Electrospun nanofibrous cellulose scaffolds with controlled microarchitecture. Carbohydr. Polym. 2014, 100, 143-149. [CrossRef] 
90. Zhang, X.; Wang, C.; Liao, M.; Dai, L.; Tang, Y.; Zhang, H.; Coates, P.; Sefat, F.; Zheng, L.; Song, J. Aligned electrospun cellulose scaffolds coated with rhBMP-2 for both in vitro and in vivo bone tissue engineering. Carbohydr. Polym. 2019, 213, 27-38. [CrossRef]

91. Zhao, X.; Zhou, L.; Li, Q.; Zou, Q.; Du, C. Biomimetic mineralization of carboxymethyl chitosan nanofibers with improved osteogenic activity in vitro and in vivo. Carbohydr. Polym. 2018, 195, 225-234. [CrossRef]

92. Chen, W.; Wang, C.; Gao, Y.; Wu, Y.; Wu, G.; Shi, X.; Du, Y.; Deng, H. Incorporating chitin derived glucosamine sulfate into nanofibers via coaxial electrospinning for cartilage regeneration. Carbohydr. Polym. 2020, 229, 115544. [CrossRef] [PubMed]

93. Khatami, S.M.; Parivar, K.; Sohi, A.N.; Soleimani, M.; Hanaee-Ahvaz, H. Acetylated hyaluronic acid effectively enhances chondrogenic differentiation of mesenchymal stem cells seeded on electrospun PCL scaffolds. Tissue Cell 2020, 65, 101363. [CrossRef] [PubMed]

94. Chen, C.-H.; Chen, S.-H.; Shalumon, K.; Chen, J.-P. Dual functional core-sheath electrospun hyaluronic acid/polycaprolactone nanofibrous membranes embedded with silver nanoparticles for prevention of peritendinous adhesion. Acta Biomater. 2015, 26, 225-235. [CrossRef] [PubMed]

95. Zha, F.; Chen, W.; Hao, L.; Wu, C.; Lu, M.; Zhang, L.; Yu, D. Electrospun cellulose-based conductive polymer nanofibrous mats: Composite scaffolds and their influence on cell behavior with electrical stimulation for nerve tissue engineering. Soft Matter 2020, 16, 6591-6598. [CrossRef] [PubMed]

96. Thunberg, J.; Kalogeropoulos, T.; Kuzmenko, V.; Hägg, D.; Johannesson, S.; Westman, G.; Gatenholm, P. In situ synthesis of conductive polypyrrole on electrospun cellulose nanofibers: Scaffold for neural tissue engineering. Cellulose 2015, 22, 1459-1467. [CrossRef]

97. Sadeghi, A.; Moztarzadeh, F.; Mohandesi, J.A. Investigating the effect of chitosan on hydrophilicity and bioactivity of conductive electrospun composite scaffold for neural tissue engineering. Int. J. Biol. Macromol. 2019, 121, 625-632. [CrossRef]

98. Joy, J.; Pereira, J.; Aid-Launais, R.; Pavon-Djavid, G.; Ray, A.R.; Letourneur, D.; Meddahi-Pellé, A.; Gupta, B. Gelatin-Oxidized carboxymethyl cellulose blend based tubular electrospun scaffold for vascular tissue engineering. Int. J. Biol. Macromol. 2018, 107, 1922-1935. [CrossRef]

99. Zhang, K.; Fan, L.; Yan, Z.; Yu, Q.; Mo, X. Electrospun biomimic nanofibrous scaffolds of silk fibroin/hyaluronic acid for tissue engineering. J. Biomater. Sci. Polym. Ed. 2012, 23, 1185-1198. [CrossRef]

100. Zhu, T.; Mao, J.; Cheng, Y.; Liu, H.; Lv, L.; Ge, M.; Li, S.; Huang, J.; Chen, Z.; Li, H. Recent progress of polysaccharide-based hydrogel interfaces for wound healing and tissue engineering. Adv. Mater. Interfaces 2019, 6, 1900761. [CrossRef]

101. Hu, H.; Xu, F.-J. Rational design and latest advances of polysaccharide-based hydrogels for wound healing. Biomater. Sci. 2020, 8, 2084-2101. [CrossRef]

102. Gupta, A.; Kowalczuk, M.; Heaselgrave, W.; Britland, S.T.; Martin, C.; Radecka, I. The production and application of hydrogels for wound management: A review. Eur. Polym. J. 2019, 111, 134-151. [CrossRef]

103. Nosar, M.N.; Salehi, M.; Ghorbani, S.; Beiranvand, S.P.; Goodarzi, A.; Azami, M. Characterization of wet-electrospun cellulose acetate based 3-dimensional scaffolds for skin tissue engineering applications: Influence of cellulose acetate concentration. Cellulose 2016, 23, 3239-3248. [CrossRef]

104. Xue, J.; He, M.; Liang, Y.; Crawford, A.; Coates, P.; Chen, D.; Shi, R.; Zhang, L. Fabrication and evaluation of electrospun PCL-gelatin micro-/nanofiber membranes for anti-infective GTR implants. J. Mater. Chem. B 2014, 2, 6867-6877. [CrossRef]

105. Tan, H.-L.; Kai, D.; Pasbakhsh, P.; Teow, S.-Y.; Lim, Y.-Y.; Pushpamalar, J. Electrospun cellulose acetate butyrate/polyethylene glycol (CAB/PEG) composite nanofibers: A potential scaffold for tissue engineering. Colloids Surf. B Biointerfaces 2020, 188, 110713. [CrossRef]

106. Kozlowska, M.; Goclon, J.; Rodziewicz, P. Intramolecular hydrogen bonds in low-molecular-weight polyethylene glycol. ChemPhysChem 2016, 17, 1143-1153. [CrossRef]

107. Atila, D.; Keskin, D.; Tezcaner, A. Cellulose acetate based 3-dimensional electrospun scaffolds for skin tissue engineering applications. Carbohydr. Polym. 2015, 133, 251-261. [CrossRef]

108. Samadian, H.; Salehi, M.; Farzamfar, S.; Vaez, A.; Ehterami, A.; Sahrapeyma, H.; Goodarzi, A.; Ghorbani, S. In vitro and in vivo evaluation of electrospun cellulose acetate/gelatin/hydroxyapatite nanocomposite mats for wound dressing applications. Artif. Cells Nanomed. Biotechnol. 2018, 46, 964-974. [CrossRef]

109. Samadian, H.; Zamiri, S.; Ehterami, A.; Farzamfar, S.; Vaez, A.; Khastar, H.; Alam, M.; Ai, A.; Derakhshankhah, H.; Allahyari, Z. Electrospun cellulose acetate/gelatin nanofibrous wound dressing containing berberine for diabetic foot ulcer healing: In vitro and in vivo studies. Sci. Rep. 2020, 10, 1-12. [CrossRef]

110. Madub, K.; Goonoo, N.; Gimié, F.; Arsa, I.A.; Schönherr, H.; Bhaw-Luximon, A. Green seaweeds ulvan-cellulose scaffolds enhance in vitro cell growth and in vivo angiogenesis for skin tissue engineering. Carbohydr. Polym. 2021, 251, 117025. [CrossRef]

111. Pezeshki-Modaress, M.; Zandi, M.; Rajabi, S. Tailoring the gelatin/chitosan electrospun scaffold for application in skin tissue engineering: An in vitro study. Prog. Biomater. 2018, 7, 207-218. [CrossRef]

112. Mei, N.; Chen, G.; Zhou, P.; Chen, X.; Shao, Z.-Z.; Pan, L.-F.; Wu, C.-G. Biocompatibility of poly( $\varepsilon$-caprolactone) scaffold modified by chitosan-the fibroblasts proliferation in vitro. J. Biomater. Appl. 2005, 19, 323-339. [CrossRef]

113. Prasad, T.; Shabeena, E.; Vinod, D.; Kumary, T.; Kumar, P.A. Characterization and in vitro evaluation of electrospun chitosan/polycaprolactone blend fibrous mat for skin tissue engineering. J. Mater. Sci. Mater. Med. 2015, 26, 28. [CrossRef]

114. Gomes, S.R.; Rodrigues, G.; Martins, G.G.; Roberto, M.A.; Mafra, M.; Henriques, C.; Silva, J.C. In vitro and in vivo evaluation of electrospun nanofibers of PCL, chitosan and gelatin: A comparative study. Mater. Sci. Eng. C 2015, 46, 348-358. [CrossRef] 
115. Noh, H.K.; Lee, S.W.; Kim, J.-M.; Oh, J.-E.; Kim, K.-H.; Chung, C.-P.; Choi, S.-C.; Park, W.H.; Min, B.-M. Electrospinning of chitin nanofibers: Degradation behavior and cellular response to normal human keratinocytes and fibroblasts. Biomaterials 2006, 27, 3934-3944. [CrossRef]

116. Min, S.-K.; Lee, S.-C.; Hong, S.-D.; Chung, C.-P.; Park, W.H.; Min, B.-M. The effect of a laminin-5-derived peptide coated onto chitin microfibers on re-epithelialization in early-stage wound healing. Biomaterials 2010, 31, 4725-4730. [CrossRef]

117. Min, B.-M.; You, Y.; Kim, J.-M.; Lee, S.J.; Park, W.H. Formation of nanostructured poly(lactic-co-glycolic acid)/chitin matrix and its cellular response to normal human keratinocytes and fibroblasts. Carbohydr. Polym. 2004, 57, 285-292. [CrossRef]

118. Ji, Y.; Ghosh, K.; Li, B.; Sokolov, J.C.; Clark, R.A.; Rafailovich, M.H. Dual-syringe reactive electrospinning of cross-linked hyaluronic acid hydrogel nanofibers for tissue engineering applications. Macromol. Biosci. 2006, 6, 811-817. [CrossRef]

119. Ji, Y.; Ghosh, K.; Shu, X.Z.; Li, B.; Sokolov, J.C.; Prestwich, G.D.; Clark, R.A.; Rafailovich, M.H. Electrospun three-dimensional hyaluronic acid nanofibrous scaffolds. Biomaterials 2006, 27, 3782-3792. [CrossRef]

120. Jeong, S.I.; Krebs, M.D.; Bonino, C.A.; Khan, S.A.; Alsberg, E. Electrospun alginate nanofibers with controlled cell adhesion for tissue engineering a. Macromol. Biosci. 2010, 10, 934-943. [CrossRef]

121. Ma, G.; Fang, D.; Liu, Y.; Zhu, X.; Nie, J. Electrospun sodium alginate/poly(ethylene oxide) core-shell nanofibers scaffolds potential for tissue engineering applications. Carbohydr. Polym. 2012, 87, 737-743. [CrossRef]

122. Augustine, R.; Rehman, S.R.U.; Ahmed, R.; Zahid, A.A.; Sharifi, M.; Falahati, M.; Hasan, A. Electrospun chitosan membranes containing bioactive and therapeutic agents for enhanced wound healing. Int. J. Biol. Macromol. 2020, 156, 153-170. [CrossRef]

123. An, J.; Zhang, H.; Zhang, J.; Zhao, Y.; Yuan, X. Preparation and antibacterial activity of electrospun chitosan/poly(ethylene oxide) membranes containing silver nanoparticles. Colloid Polym. Sci. 2009, 287, 1425-1434. [CrossRef]

124. Hadisi, Z.; Farokhi, M.; Bakhsheshi-Rad, H.R.; Jahanshahi, M.; Hasanpour, S.; Pagan, E.; Dolatshahi-Pirouz, A.; Zhang, Y.S.; Kundu, S.C.; Akbari, M. Hyaluronic acid (HA)-based silk fibroin/zinc oxide core-shell electrospun dressing for burn wound management. Macromol. Biosci. 2020, 20, 1900328. [CrossRef] [PubMed]

125. Dodero, A.; Scarfi, S.; Pozzolini, M.; Vicini, S.; Alloisio, M.; Castellano, M. Alginate-based electrospun membranes containing $\mathrm{ZnO}$ nanoparticles as potential wound healing patches: Biological, mechanical, and physicochemical characterization. ACS Appl. Mater. Interfaces 2019, 12, 3371-3381. [CrossRef] [PubMed]

126. Song, J.; Remmers, S.J.; Shao, J.; Kolwijck, E.; Walboomers, X.F.; Jansen, J.A.; Leeuwenburgh, S.C.; Yang, F. Antibacterial effects of electrospun chitosan/poly(ethylene oxide) nanofibrous membranes loaded with chlorhexidine and silver. Nanomed. Nanotechnol. Biol. Med. 2016, 12, 1357-1364. [CrossRef] [PubMed]

127. Ranjith, R.; Balraj, S.; Ganesh, J.; Milton, M.J. Therapeutic agents loaded chitosan-based nanofibrous mats as potential wound dressings: A review. Mater. Today Chem. 2019, 12, 386-395. [CrossRef]

128. Alavarse, A.C.; de Oliveira Silva, F.W.; Colque, J.T.; da Silva, V.M.; Prieto, T.; Venancio, E.C.; Bonvent, J.-J. Tetracycline hydrochloride-loaded electrospun nanofibers mats based on PVA and chitosan for wound dressing. Mater. Sci. Eng. C 2017, 77, 271-281. [CrossRef]

129. Ahire, J.; Robertson, D.; van Reenen, A.; Dicks, L. Polyethylene oxide (PEO)-hyaluronic acid (HA) nanofibers with kanamycin inhibits the growth of Listeria monocytogenes. Biomed. Pharmacother. 2017, 86, 143-148. [CrossRef]

130. Amiri, N.; Ajami, S.; Shahroodi, A.; Jannatabadi, N.; Darban, S.A.; Bazzaz, B.S.F.; Pishavar, E.; Kalalinia, F.; Movaffagh, J. Teicoplanin-loaded chitosan-PEO nanofibers for local antibiotic delivery and wound healing. Int. J. Biol. Macromol. 2020, 162, 645-656. [CrossRef]

131. Khan, G.; Yadav, S.K.; Patel, R.R.; Kumar, N.; Bansal, M.; Mishra, B. Tinidazole functionalized homogeneous electrospun chitosan/poly ( $\varepsilon$-caprolactone) hybrid nanofiber membrane: Development, optimization and its clinical implications. Int. J. Biol. Macromol. 2017, 103, 1311-1326. [CrossRef]

132. Yang, S.; Zhang, X.; Zhang, D. Electrospun chitosan/poly(vinyl alcohol)/graphene oxide nanofibrous membrane with ciprofloxacin antibiotic drug for potential wound dressing application. Int. J. Mol. Sci. 2019, 20, 4395. [CrossRef]

133. Fazli, Y.; Shariatinia, Z. Controlled release of cefazolin sodium antibiotic drug from electrospun chitosan-polyethylene oxide nanofibrous Mats. Mater. Sci. Eng. C 2017, 71, 641-652. [CrossRef]

134. Chuysinuan, P.; Pengsuk, C.; Lirdprapamongkol, K.; Techasakul, S.; Svasti, J.; Nooeaid, P. Enhanced structural stability and controlled drug release of hydrophilic antibiotic-loaded alginate/soy protein isolate core-sheath fibers for tissue engineering applications. Fibers Polym. 2019, 20, 1-10. [CrossRef] 